\title{
Role of Fire in the Germination Ecology of Fountain Grass (Pennisetum setaceum), an Invasive African Bunchgrass in Hawai ${ }^{\circ}{ }^{1}$
}

\author{
Edith Adkins, ${ }^{2}$ Susan Cordell, ${ }^{3}$ and Donald R. Drake ${ }^{2}$
}

\begin{abstract}
Field and laboratory studies were carried out to test factors expected to be relevant for the germination of fountain grass: (1) light; (2) emergence of fountain grass seedlings from depths of $0,2.5$, and $5 \mathrm{~cm}$; (3) fire passing over exposed and buried seeds; (4) laboratory heat treatment mimicking exposure to grass fire. Both fire in the field and heat applied in the laboratory killed fountain grass seeds. In the laboratory, some seeds were killed after exposure to $75^{\circ} \mathrm{C}$ for $3 \mathrm{~min}$, and all seeds were killed at $100^{\circ} \mathrm{C}$. During the prescribed burns, temperatures at the soil surface reached at least $204^{\circ} \mathrm{C}$, but temperatures at depths of 2.5 and $5 \mathrm{~cm}$ showed no measurable change. Light is not essential for germination of fountain grass seeds, and seedlings can emerge from depths of at least $5 \mathrm{~cm}$. Both of these traits contribute to the invasive capacity of the species. Because fountain grass seeds are killed at temperatures in excess of $100^{\circ} \mathrm{C}$, the species depends on its ability to resprout and quickly set seed after fire for population growth and spread. Seeds buried beneath the soil may escape exposure to fire, and substrate heterogeneity may provide refuge from temperature extremes experienced during fire. The morphology of fountain grass seeds likely inhibits burial in the soil for the most part, but there are several potential burial mechanisms. Prescribed burns could prove to be a useful tool for fountain grass control in large, degraded sites where fountain grass has invaded but only when coupled with additional control measures.
\end{abstract}

InVASION OF NATIVE ecosystems by alien grasses has become a worldwide phenomenon (D'Antonio and Vitousek 1992), and island ecosystems are particularly vulnerable to alien plant invasion (Loope and Mueller-Dombois 1989, Simberloff 1995). Alien plant species threaten the native biota of Hawail $i$ in rising numbers (Denslow 2003, Asner et al. 2008).

\footnotetext{
${ }^{1}$ Research funding was provided by the Joint Fire Science Program, the Charles H. Lamoureux Fellowship in Plant Conservation, and the West Hawai'i Wildfire Management Organization. Manuscript accepted 12 April 2010.

${ }^{2}$ Botany Department, University of Hawai'i at Mānoa, Honolulu, Hawai'i.

${ }^{3}$ Institute of Pacific Islands Forestry, U.S. Department of Agriculture Forest Service, Hilo, Hawai'i.
}

Pacific Science (2011), vol. 65, no. 1:17-25

doi: 10.2984/65.1.017

(C) 2011 by University of Hawai'i Press

All rights reserved
The Hawaiian Islands now play host to many alien grass species including fountain grass, Pennisetum setaceum (Forssk.) Choiv. Most of these alien grasses were brought in as ornamental species or fodder for livestock, and some have quickly spread and now dominate large portions of previously native ecosystems (Smith 1985, D'Antonio and Vitousek 1992). Several of the grass species problematic in Hawai'i are a concern throughout the Indo-Pacific (D'Antonio and Vitousek 1992). Clearing of lands for agriculture or cattle ranching usually prompts the introduction of alien grasses, and the ensuing grass/fire cycle facilitates their spread into neighboring native ecosystems (D'Antonio and Vitousek 1992). In Hawai $i$, these grasses also colonize barren lava flows (Hughes et al. 1991, Williams and Black 1994), creating contiguous fuel loads interconnecting otherwise isolated forest patches. As a result, the likelihood and propagation of fire is greatly increased.

Many of these invasive grasses evolved in habitats prone to frequent fire and have 
developed mechanisms for regeneration after fire (Vogl 1975). The native Hawaiian flora is thought to have evolved under infrequent exposure to fire (Vogl 1975) and is less capable of regeneration following fire (Smith and Tunison 1992). When alien grasses colonize an area, the difference in regenerative ability initiates a vicious cycle (D'Antonio and Vitousek 1992). Each fire further reduces the coverage by native flora and thereby clears land for the expansion of the grass (D'Antonio and Vitousek 1992). Furthermore, the presence of grass chronically alters the processes in ecosystems such as Hawaiian dry forests by competing for light, nutrients, and water (Blackmore and Vitousek 2000, Cabin et al. 2002, Cordell et al. 2002, Mack and D'Antonio 2003, Litton et al. 2006, Cordell and Sandquist 2008, Litton et al. 2008).

Fountain grass, a $\mathrm{C}_{4}$ bunchgrass native to North Africa, was introduced to Hawai'i as an ornamental during the early 1900s (Wagner et al. 1999). This drought-tolerant, rapidgrowing species has escaped from cultivation in Australia, Fiji, North America, South Africa, and Hawai'i (Chippindall and Crook 1976, Williams et al. 1995, Milton et al. 1998). Fountain grass has spread throughout the islands of Hawai'i, particularly on the island of Hawaic $i$, and it has become the dominant cover in many dry, leeward areas (Williams and Black 1994, Goergen and Daehler 2002, Poulin et al. 2007). Fountain grass is particularly problematic in Hawai'i because it invades lava flows, disrupting primary succession (Tunison 1992) by preventing colonization of native species. Fountain grass forms monotypic stands with large amounts of dead mass that fuels fires (Tunison 1992). The fires fueled by exotic grasses are extremely damaging to the native vegetation because many native Hawaiian shrubs and trees burn readily and do not regenerate well, if at all, after fire (Smith and Tunison 1992). In contrast, individual fountain grass culms regenerate rapidly, flower, and set seed within a few months after fire (Goergen and Daehler 2002). Although fountain grass may resprout from cut or burned culms, it lacks vegetative reproduction and is therefore reliant upon seeds for establishment of new individuals and population growth (Goergen and Daehler 2001).

Knowledge of basic germination requirements and seed ecology of fountain grass is lacking. Factors such as light requirement, depth of emergence, and heat/fire tolerance may affect seedling recruitment and play a role in the further spread of this invasive grass. It is of interest then to investigate which aspects of its seed and germination ecology may aid in the invasive capacity of fountain grass.

Herbaceous plants have two primary modes for survival following the passage of fire; either they resprout from underground storage tissues or recruit new individuals from a seed bank (Pausas et al. 2004, Paula and Pausas 2008). During a fire, seeds may be killed unless protected by some kind of adaptation or by an insulating layer of soil (Baskin and Baskin 1989). Protected seeds may either be stimulated to germinate or remain dormant or quiescent (Baskin and Baskin 1989, Paula and Pausas 2008). Seeds can avoid the effects of fire through a number of mechanisms including burial in the soil either by animals or with the aid of hygroscopic awns (Ernst et al. 1992). Because grassland fires move quickly, soil temperatures may remain unchanged even in the upper layers, thereby sparing buried seeds from temperature extremes (Gillon 1983). In contrast, seeds resting on the soil surface can be completely destroyed by direct combustion or exposure to temperatures generated during fires (Ernst et al. 1992).

The objectives of this study were to (1) determine whether fountain grass seeds require light for germination; (2) determine the potential depth of seedling emergence from soil; and (3) examine the ability of seeds to survive high temperatures and/or fire.

\section{MATERIALS AND METHODS}

\section{Site Description}

Our field experiments utilized the design and subsequent prescribed burns of a large-scale Joint Fire Science Program project investigating methods for reducing the fuel biomass 
of fountain grass (Castillo et al. 2007). Field studies were conducted on a 97 ha site in $\mathrm{Pu}^{6} \mathrm{u}$ Anahulu Game Management Area located on the northwestern slopes of Mauna Loa at $19^{\circ} 50^{\prime} \mathrm{N}$ lat. and $155^{\circ} 47^{\prime} 20^{\prime \prime} \mathrm{W}$ long. on the island of Hawai'i. The elevation ranges from 660 to $800 \mathrm{~m}$. The site once contained an extremely diverse array of dry forest flora (Rock 1913). Areas containing remnants of dry forest exist and are excluded from experimental treatments. Currently, the site is extensively overgrown by fountain grass. Feral goats (Capra bircus bircus) and sheep (Ovis aries) are found throughout. The substrate is heterogeneous and consists mainly of ' $a$ ' $\bar{a}$ and $p \bar{a}$ hoeboe lava flows originating from Mauna Loa volcanics that range in age from 750 to 5,000 yr old (Wolf and Morris 1996). The study site has many bare lava rock outcroppings and fountain grass distributed in large patches throughout. The soil at the site is classified as euic, isothermic, shallow, and lithic ustifolist (Litton et al. 2006) and has a patchy distribution with a high organic content, primarily composed of fountain grass leaf litter. Mean rainfall is approximately $50 \mathrm{~cm}$ per year (Giambelluca et al. 1986). Rain is unevenly distributed throughout the year, with most rainfall occurring in the winter.

\section{Prescribed Burns}

The prescribed burns were conducted in January 2004. The burn prescription required $6.1 \mathrm{~m}$ wind speed of $8.3-16.7 \mathrm{~km} / \mathrm{hr}$ from the north yielding a midflame wind speed of $5-10 \mathrm{~km} / \mathrm{hr}$, relative humidity of $60 \%-70 \%$, air temperature of $13^{\circ}-20^{\circ} \mathrm{C}$, and 1 -hr dead fuel moisture content of $15 \%-18 \%$ (Castillo et al. 2007).

\section{Collection and Selection of Seeds}

Seeds for germination trials were collected from the field site in November 2003 and March 2004 and stored in paper bags at $\sim 23^{\circ} \mathrm{C}$ for 2 months. Previous germination studies done by Goergen and Daehler (2001) indicated that fresh seeds germinate readily and do not exhibit dormancy. Before experi- mentation, seeds were sorted to determine viability. Seeds expected to be viable were selected for use in experiments. The glumes of the spikelet were spread for visual inspection. Those seeds (defined as the entire dispersal unit composed of the spikelet with involucral bristles [Wagner et al. 1999]) containing plump, beige-colored embryos were deemed viable. Seeds were weighed to determine average weight.

For all experiments, seeds remained within the dispersal unit so as to best understand the germination ecology of these seeds in their natural state (Baskin and Baskin 2001). Sample size for all experiments was five replicates of 10 seeds. Seeds were distributed on moist sand in petri dishes sealed with parafilm $(\mathrm{Pe}-$ chiney Plastic Packaging, 289 River Street, Menasha, Wisconsin 54952) to prevent drying (Baskin and Baskin 2001) and were placed under shaded conditions on a balcony at the University of Hawai' $i$ at Mānoa for 10 days. Mean maximum daily temperature was $27.5^{\circ} \mathrm{C}$, and mean minimum temperature was $21.1^{\circ} \mathrm{C}$ (C. Nakahashi, unpubl. data). Initial germination trials were done to establish time to germination and showed that fountain grass seeds germinated rapidly, within 3 to 5 days. Seeds were monitored for 3 weeks, and no additional germination was noted beyond 10 days (Nonner 2005).

\section{Germination and Emergence Experiments}

The requirement of light for germination was tested in the laboratory. Seeds were placed in petri dishes filled with moist sand. Dishes were either sealed with only parafilm to prevent drying or sealed with parafilm and wrapped in heavy-duty aluminum foil (0.1 $\mathrm{mm}$ ply) to block the access of light. Both treatments were placed next to one another under shade and allowed to germinate for 15 days. The arcsine square-root transformations of percentages (Sokal and Rohlf 1995) of germinated seeds were subjected to twosided $t$-test to assess the significance of the difference between the light and the dark treatments.

Seeds were buried at depths of $0,2.5$, and $5 \mathrm{~cm}$ in $\varnothing 15$ by $11 \mathrm{~cm}$ pots filled with potting 
soil mix (Miracle Grow Enriched Garden Soil; $0.10 \%$ total $\mathrm{N}, 0.05 \%$ available $\mathrm{P}$, $0.10 \%$ soluble potash) to test the ability of seedlings to emerge. In two groups of pots, seeds were covered with either 5 or $2.5 \mathrm{~cm}$ of lightly packed potting mix. The seeds of a third group of pots were pressed flush with the soil surface layer and left uncovered. Pots were watered as needed to keep the soil moist. After 15 days, those seeds that had emerged were counted and removed. The arcsine square-root transformed percentages of emerged seedlings were analyzed by oneway analysis of variance (ANOVA).

\section{Effect of Fire/Heat on Seed Germination}

The effect of fire on seed viability was tested during prescribed burns that were administered in January 2004 (see Castillo et al. [2007] for experimental design). Three burn units were randomly selected and seeds contained in aluminum packets were distributed at random locations along a $100 \mathrm{~m}$ transect through the center of each burn unit before the burn. Seed packets were made of a 10 $\mathrm{cm}$ square of heavy-duty aluminum foil $(0.1$ $\mathrm{mm}$ ply) folded in half and crimped along the edges (10 seeds per packet, five packets for each depth). The seed-containing packets were either placed on the surface layer and anchored by a nail or buried at depths of 2.5 and $5 \mathrm{~cm}$ to test extent of protection from heat by soil.

Maximal temperatures reached during burns were monitored using aluminum packets containing shavings of Tempilstiks (Tempil, Inc., Hamilton Boulevard, South Plainfield, New Jersey 07080), temperaturesensitive indicating crayons, placed alongside seed packets at the same depth of burial. Each temperature-monitoring packet ( 5 by 5 $\left.\mathrm{cm}^{2}\right)$ contained nine subpackets $\left(1 \mathrm{~cm}^{2}\right)$, each filled with a temperature indicator melting at one of the given temperatures: $52^{\circ}, 66^{\circ}, 70^{\circ}$, $93^{\circ}, 107^{\circ}, 121^{\circ}, 135^{\circ}, 149^{\circ}$, and $204^{\circ} \mathrm{C}$. The seed packets and temperature indicators were collected immediately after the burn and taken for analysis. Seeds in packets exposed to fire on the soil surface were completely charred and incapable of germination. Ger- mination trials were done as described in the previous experiments. The arcsine squareroot transformations of percentages of germinated seeds were subjected to two-sided $t$-test to assess the significance of the difference in burial depth.

The effect of short periods of laboratory heat treatment was also assessed in experiments at temperatures established during the prescribed burns: $50^{\circ}, 75^{\circ}, 100^{\circ}, 125^{\circ}, 150^{\circ}$, $175^{\circ}$, and $200^{\circ} \mathrm{C}$ applied for $1-$ and 3 -min periods in a preheated oven. These seeds were placed on aluminum weighing boats to facilitate rapid insertion and removal without altering oven temperatures. After heat treatment, the seeds were placed on moist sand in petri dishes and allowed to germinate. After arcsine square-root transformation and testing for unequal variances (Levene's Test, nonsignificant), an ANOVA was used to test for differences between treatments.

\section{RESULTS}

\section{Germination and Emergence Experiments}

Fountain grass seeds containing embryos, within their dispersal unit, had a mean weight of $3.23 \mathrm{mg}$. Initial germination trials of sorted seeds stored for 2 months in the laboratory under cool, dry, and dark conditions resulted in an average germination of $90 \%$ (Nonner 2005).

Of seeds exposed to light, $88 \%$ germinated (range $80-100$ ), and $80 \%$ of seeds kept in the dark germinated (range 70-100). A twosided $t$-test revealed no significant difference between the treatments $(t=0.81, \mathrm{df}=7$, $P=.442, n=5$ ), indicating that light is not a requirement for the germination of these seeds.

Seeds placed on the soil surface had a mean germination rate of $82 \%$, whereas seeds buried at $2.5 \mathrm{~cm}$ emerged at a rate of $78 \%$, and seeds buried at $5 \mathrm{~cm}$ emerged at a rate of $66 \%$ (Figure 1). These differences are not significant $(F=1.35, P=0.29, n=5)$, although they seem to indicate a weak reduction of emergence rate with increasing depth (Figure 1). 


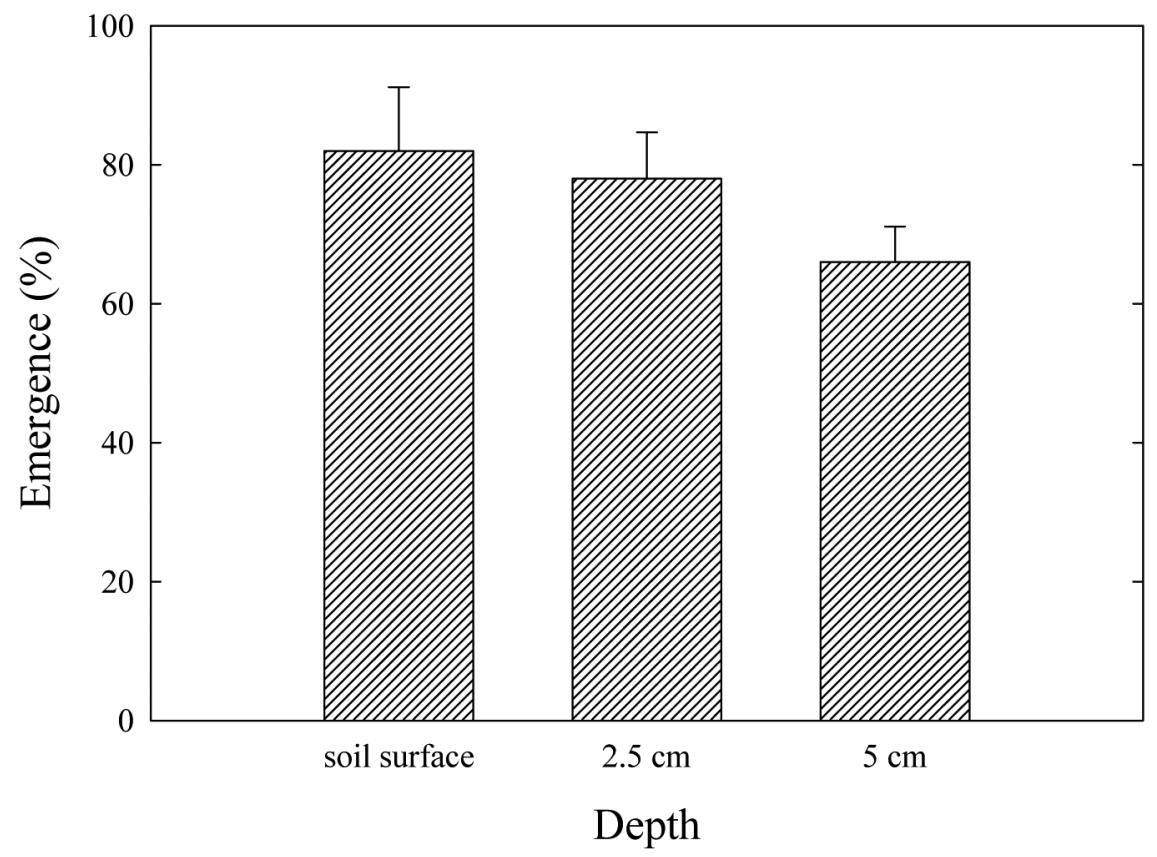

FigurE 1 . Mean \pm 1 SEM percentage emergence of seedlings from seeds buried at $0,2.5$, and $5 \mathrm{~cm}$ soil depths in $\varnothing 15$ by $11 \mathrm{~cm}$ pots after 15 days, $n=5$, with 10 seeds per replicate.

\section{Effect of Fire/Heat on Seed Germination}

The temperature indicators on the soil surface during the prescribed burns showed that temperatures ranged from $52^{\circ}$ to at least $204^{\circ} \mathrm{C}$ (mean $159.8^{\circ} \mathrm{C}$, median $204^{\circ} \mathrm{C}$ ). On average, only $1 \%$ of the seeds germinated after the passage of fire (Figure 2). These seeds were charred except for one seed (of 150) that escaped combustion. Therefore statistical comparisons were restricted to those seeds placed at 2.5 and $5 \mathrm{~cm}$ soil depths. Temperatures at 2.5 and $5 \mathrm{~cm}$ depths remained below $52^{\circ} \mathrm{C}$ (Figure 2). Their mean germination rates were $40.7 \%$ and $38.8 \%$, respectively. A two-sided $t$-test $(t=0.05, \mathrm{df}=27, P=$ $0.959)$ revealed no significant difference between percentage germinations at 2.5 and $5 \mathrm{~cm}$ soil depths. These experiments indicate that limited penetration of heat into the soil limits the impact of fires on seed germination.

In laboratory heat treatments, applied at $50^{\circ}$ and $75^{\circ} \mathrm{C}$ for $1-$ and 3-min treatments, germination rates did not differ significantly from the control; however a trend of decreasing germination was seen as temperatures and treatment time increased. No germination occurred following exposure to temperatures of $100^{\circ} \mathrm{C}$ or greater (Figure 3).

\section{DISCUSSION}

The seeds of fountain grass are nondormant and germinate readily in the light or dark and on the soil surface. Our results showed that seedlings can emerge from depths of at least $5 \mathrm{~cm}$. Prescribed burns may destroy seeds on the soil surface but do not prevent the germination of seeds buried at depths of 2.5 and $5 \mathrm{~cm}$. Laboratory heat applications were consistent with field results, indicating that seeds are killed after exposure to temperatures of at least $100^{\circ} \mathrm{C}$.

The invasion of native Hawaiian ecosystems by fountain grass further threatens already vulnerable plant communities through its ability to carry fire and its suppression of 


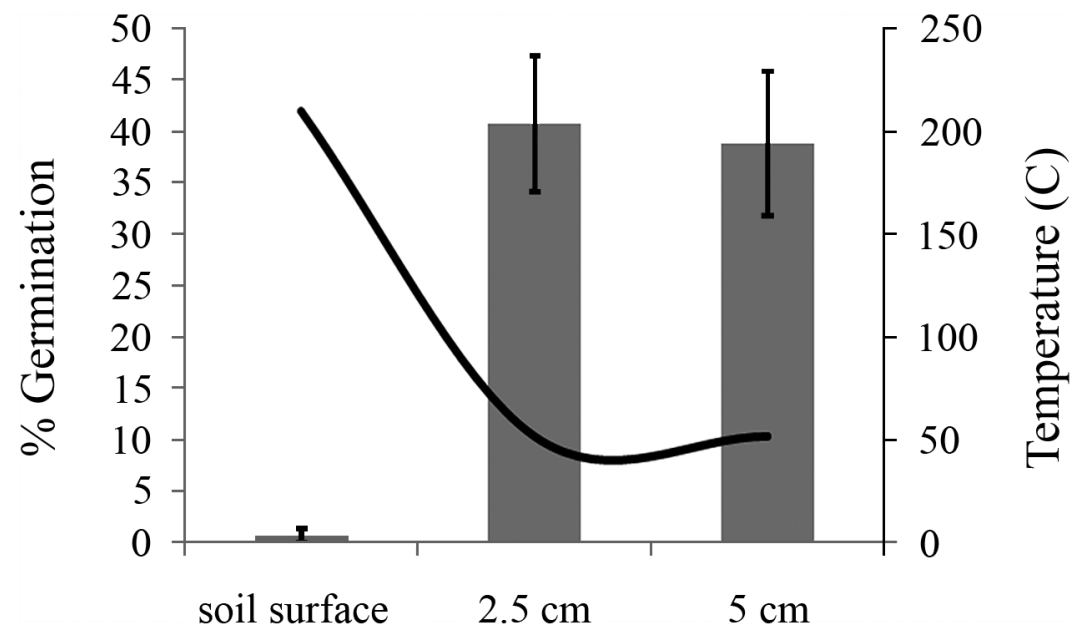

FIgURE 2. Mean \pm 1 SEM percentage germination of fountain grass seeds placed at the soil surface and depths of 2.5 and $5 \mathrm{~cm}$ during the passage of fire. Values represent mean percentage germination from three burn units with five replicates per burn unit; total $n=15$ per treatment. The plotted line indicates maximum soil temperatures measured using Tempilstik packets during prescribed burns in January 2004 at Pu'u Anahulu Game Management Area, Hawai'i.

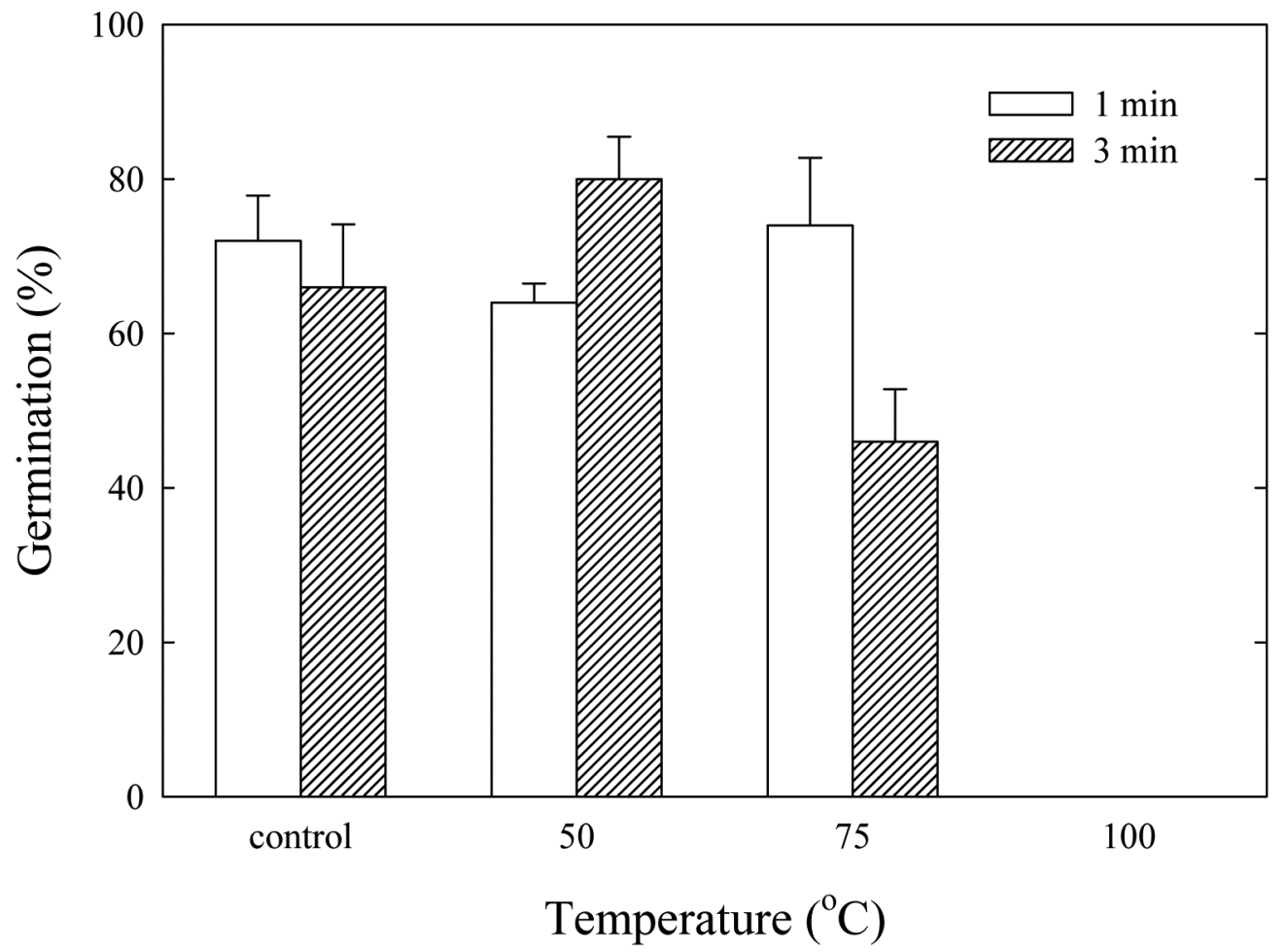

FIGURE 3. Mean \pm 1 SEM percentage germination of fountain grass seeds following dry heat treatment at exposure times of 1 and $3 \mathrm{~min}$. No seeds germinated under the $100^{\circ} \mathrm{C}$ treatment. Values represent five replicates of 10 seeds per temperature and exposure time $(n=5)$. 
native plant growth and recruitment and alteration of ecosystem processes (Cabin et al. 2002, Cordell and Sandquist 2008, Litton et al. 2008). Several traits are commonly found in species with invasive capacity including the production of a large number of seeds, long-distance dispersal, long-lived seeds, and seeds that have no special germination requirements and lack dormancy (Vila and Lloret 2000).

Fountain grass is a prolific seeder with wind-dispersed seeds that do not exhibit dormancy (Goergen and Daehler 2001). These "weedy" attributes may impart an advantage after some disturbance such as fire or trampling by ungulates, encouraging establishment of new populations. Seeds exposed to high temperatures occurring at the soil surface during prescribed burns are incapable of germinating, but seeds can be effectively protected by burial in the soil. Thus fire has serious impacts only for seeds on the soil surface. The seeds of fountain grass bear involucral bristles, making deep incorporation into the soil an unlikely event (Peart 1981). However, in Hawai' $i$, the fuel loads provided by fountain grass tend to be patchy due to the heterogeneous landscape of the lava flows, so that seeds may escape due to the spatial discontinuity of fires. The substrate may also offer refugia in cracks and holes where seeds can escape the lethal temperatures and occupy a favorable microsite for germination. Ungulates may also play a role in the burial of seeds via trampling.

For fountain grass, recruitment of new individuals is limited to seed germination, not vegetative reproduction, leaving a limited window for establishment of new populations. This may indicate an opportunity for control of fountain grass through the use of prescribed burns in concert with other control measures. If burns can be timed with flowering events, before seed set, the limited number of viable seeds released into an area should reduce the recruitment of new individuals. Subsequent removal of regenerating culms would then be necessary to further limit input of seeds into a given area. Prescribed burns could prove to be a useful tool for fountain grass control in larger degraded sites (areas lacking native forest) such as at those found on the island of Hawai' $i$ and elsewhere where fountain grass has invaded but only when coupled with additional control measures.

\section{ACKNOWLEDGMENTS}

We thank Mick Castillo, Danielle Frohlich, Jen Rodwell, and Alex Wegmann for assistance in the field and greenhouse and Pat $\mathrm{Al}$ drich, Curt Daehler, and Clifford Morden for their support and guidance. Chris Nakahashi provided unpublished outdoor temperature data for germination trials. Carol Baskin, Wolfgang Nonner, and Becky Ostertag provided helpful comments on early drafts of the manuscript.

\section{Literature Cited}

Asner, G. P., R. F. Hughes, P. M. Vitousek, D. E. Knapp, T. Kennedy-Bowdoin, J. Boardman, R. E. Martin, M. Eastwood, and R. O. Green. 2008. Invasive plants transform the three-dimensional structure of rain forests. Proc. Natl. Acad. Sci. U.S.A. 105:4519-4523.

Baskin, C. C., and J. M. Baskin. 1989 Physiology of dormancy and germination in relation to seed bank ecology. Pages 53-66 in M. A. Leck, V. T. Parker, and R. L. Simpson, eds. Ecology of soil seed banks. Academic Press, San Diego.

2001. Ecologically meaningful germination studies. Pages 5-20 in Seeds: Ecology, biogeography, and evolution of dormancy and germination. Academic Press, San Diego.

Blackmore, M., and P. M. Vitousek. 2000. Cattle grazing, forest loss, and fuel loading in a dry forest ecosystem at $\mathrm{Pu}^{\prime} \mathrm{u}$ Wa'aWa'a Ranch, Hawaii. Biotropica 32:625-632.

Cabin, R. J., S. G. Weller, D. H. Lorence, S. Cordell, and L. J. Hadway. 2002. Effect of microsite, water, weeding, and direct seeding on the regeneration of native and alien species within a Hawaiian dry forest preserve. Biol. Conserv. 104:181-190. 
Castillo, J. M., G. Enriques, M. Nakahara, D. Weise, L. Ford, R. Moraga, and R. Vihnanek. 2007. Effects of cattle grazing, glyphosate, and prescribed burning on fountain grass fuel loading in Hawai'i. Pages 230239 in R. E. Masters and K. E. M. Galley, eds. Proceedings of the 23rd Tall Timbers Fire Ecology Conference: Fire in grassland and shrubland ecosystems. Tall Timbers Research Station, Tallahassee, Florida.

Chippindall, L. K. A., and A. O. Crook. 1976. Grasses of southern Africa, Part 183. M. O. Collins, Salisbury (Harare), Zimbabwe.

Cordell, S., R. J. Cabin, S. G. Weller, and D. H. Lorence. 2002. Simple and costeffective methods control fountain grass in dry forests (Hawai $(i)$. Ecol. Restor. 20:139-140.

Cordell, S., and D. R. Sandquist. 2008. The impact of an invasive African bunchgrass (fountain grass) on water availability and productivity of canopy trees within a tropical dry forest in Hawaii. Funct. Ecol. 22:1008-1017.

D'Antonio, C. M., and P. M. Vitousek. 1992. Biological invasions by exotic grasses, the grass/fire cycle, and global change. Annu. Rev. Ecol. Syst. 23:63-87.

Denslow, J. 2003. Weeds in paradise: Thoughts on the invisibility of tropical islands. Ann. Mo. Bot. Gard. 90:119-127.

Ernst, W. H. O., E. M. Veenendaal, and M. M. Kebakile. 1992. Possibilities for dispersal in annual and perennial grasses in a savannah in Botswana. Vegetatio 102:111.

Giambelluca, T. W., M. A. Nullet, and T. A. Schroeder. 1986. Rainfall Atlas of Hawaii. State of Hawai'i, Department of Land and Natural Resources, Division of Water and Land Development, Honolulu.

Gillon, D. 1983. The fire problem in tropical savannas. Pages 617-641 in F. Bourliere, ed. Ecosystems of the world. Vol. 13. Elsevier, Amsterdam.

Goergen, E., and C. C. Daehler. 2001. Reproductive ecology of a native Hawaiian grass (Heteropogon contortus; Poaceae) versus its invasive alien competitor (Pennisetum setaceum; Poaceae). Int. J. Plant Sci. 162:317-326.
2002. Factors affecting seedling recruitment in an invasive grass (Pennisetum setaceum) and a native grass (Heteropogon contortus) in the Hawaiian Islands. Plant Ecol. 161:147-156.

Hughes, F., P. M. Vitousek, and T. Tunison. 1991. Alien grass invasion and fire in the seasonal submontane zone of Hawaii. Ecology 72:743-746.

Litton, C. M., D. R. Sandquist, and S. Cordell. 2006. Effects of non-native grass invasion on above-ground carbon pools and tree population structure in a tropical dry forest of Hawaii. For. Ecol. Manage. 231:105-113.

2008. A non-native grass increases soil carbon flux in a Hawaiian tropical forest. Glob. Change Biol. 14:726-739.

Loope, L. L., and D. Mueller-Dombois. 1989. Characteristics of invaded islands. Pages 257-280 in J. Drake, F. Di Castri, R. Groves, F. Kruger, H. Mooney, M. Rejmanek, and M. Williamson, eds. Biological invasions. John Wiley and Sons, London.

Mack, M. C., and C. M. D’Antonio. 2003. Exotic grasses alter controls over soil nitrogen dynamics in a Hawaiian woodland. Ecol. Appl. 13:154-166.

Milton, S. J., J. H. Hoffmann, R. C. K. Bowie, J. D. Amico, M. Griffiths, D. Joubert, D. Loewenthal, N. N. Moinde, C. Seymour, M. V. Toral-Granda, and R. Wiseman. 1998. Invasive fountain grass on the Cape Peninsula. S. Afr. J. Sci. 94:57-58.

Nonner, E. D. 2005. Seed bank dynamics and germination ecology of fountain grass (Pennisetum setaceum). M.S. thesis, University of Hawai'i at Mānoa, Honolulu.

Paula, S., and J. G. Pausas. 2008. Burning seeds: Germinative response to heat treatments in relation to resprouting ability. J. Ecol. 96:543-552.

Pausas, J. G., R. A. Bradstock, D. A. Keith, J. E. Keeley, and The GCTE Network. 2004. Plant functional traits in relation to fire in crown-fire ecosystems. Ecology 85:1085-1100.

Peart, M. H. 1981. Further experiments on the biological significance of the morphol- 
ogy of seed-dispersal units in grasses. J. Ecol. 69:425-436.

Poulin, J., A. K. Sakai, S. G. Weller, and T. Nguyen. 2007. Phenotypic plasticity, precipitation, and invasiveness in the firepromoting grass Pennisetum setaceum (Poaceae). Am. J. Bot. 94:533-541.

Rock, J. F. 1913. The indigenous trees of the Hawaiian Islands. Pacific Tropical Botanical Garden, Lāwa'i, Kaua'i, Hawai'i.

Simberloff, D. 1995. Why do introduced species appear to devastate islands more than mainland areas? Pac. Sci. 49:87-97.

Smith, C. W. 1985. Impact of alien plants on Hawai'i's native biota. Pages 180-250 in C. P. Stone and J. M. Scott, eds. Hawai'i's terrestrial ecosystems: Preservation and management. Cooperative National Parks Resources Studies Unit, University of Hawai'i at Mānoa, Honolulu.

Smith, C. W., and T. Tunison. 1992. Fire and alien plants in Hawai'i: Research and management implications for native ecosystems. Pages 394-408 in C. P. Stone, C. W. Smith, and J. T. Tunison, eds. Alien plant invasion in native ecosystems of Hawai' $i$ : Management and research. Cooperative National Parks Resources Studies Unit, University of Hawai'i at Mānoa, Honolulu.

Sokal, R. R., and F. J. Rohlf. 1995. Biometry: The principles and practice of statistics in biological research. 3rd ed. W. H. Freeman and Company, San Francisco.

Tunison, J. T. 1992. Fountain grass control in Hawai'i Volcanoes National Park: Management considerations and strategies. Pages 376-393 in C. P. Stone, C. W. Smith, and J. T. Tunison, eds. Alien plant invasions in native ecosystems of Hawai'i: Management and research. Cooperative National Parks Resources Studies Unit, University of Hawai'i at Mānoa, Honolulu. Vila, M., and F. Lloret. 2000. Seed dynamics of the mast seeding tussock grass Ampelodesmos mauritanica in Mediterranean shrublands. J. Ecol. 88:479-491.

Vogl, R. J. 1975. Fire: A destructive menace or a natural process? Pages 261-289 in J. Cairns Jr., K. L. Dickson, and E. E. Herricks, eds. Recovery and restoration of damaged ecosystems. University Press of Virginia, Charlottesville.

Wagner, W. L., D. R. Herbst, and S. H. Sohmer. 1999. Manual of the flowering plants of Hawai'i. Rev. ed. University of Hawai'i Press, Honolulu.

Williams, D. G., and R. A. Black. 1994. Drought response of a native and introduced Hawaiian grass. Oecology 97:512519.

Williams, D. G., R. N. Mack, and R. A. Black. 1995. Ecophysiology of introduced Pennisetum setaceum on Hawaii: The role of phenotypic plasticity. Ecology 76:1569-1580.

Wolf, E. W., and J. Morris. 1996. Geologic map of the island of Hawaii. Misc. Investigation Series. Map I-2524A, scale 1:100,000. U.S. Geological Survey. 
